Ann. Biol. anim. Bioch. Biophys., 1978, 18 (4), 781-785.

\title{
Immunological relatedness of gonadotrophins of various fishes as shown by radioimmunoassays
}

\author{
par E. S. P. TAN *, J. M. DODD
}

Department of Zoology, University College of North Wales Bangor, Gwynedd United Kingdom.

\begin{abstract}
Summary. Pituitary extracts and plasmas of 35 species of fish were tested in two radioimmunoassay (RIA) systems, a salmon-salmon homologous RIA and a salmon-carp heterologous RIA, in which the same antiserum, raised against salmon gonadotrophin, SG-G100, was employed. In the homologous RIA, most salmonid species tested, except for the powan and ayu, cross-reacted in a manner identical with that of the standard, SG-DEAE-3. Nonparallelism of inhibition curves were found in 13 non-salmonid species while 3 others showed non cross-reaction. In the heterologous RIA, all cyprinids, except the rudd, and alt salmonids, except the ayu, as well as 9 other species, gave inhibition curves parallel to that of the standard purified carp gonadotrophin. These results may indicate that immunological properties of fish gonadotrophins do not correspond to knowr phylogenetic relationships of fishes.
\end{abstract}

\section{Introduction.}

The objective of this study is to evaluate, from an immunological viewpoint, the concept of species specificity of fish gonadotrophins on the basis of cross-reactivity of pituitary extracts and, when available, plasmas of 35 species of fishes in two RIA systems for teleost gonadotrophins namely, a salmon-salmon homologous RIA and a salmon-carp heterologous RIA, in each of which the same antiserum against salmon (Oncorhynchus tshawytscha) gonadotrophin (SG-G100; Donaldson et al., 1972) was employed.

\section{Materials and methods.}

a) The RIA systems. - The development of these two RIA systems has been already presented (Tan, 1976a). Full technical details and a validation as complete as possible of these two systems have been described (Tan, 1976b).

b) Preparation of samples. - Pituitaries were homogenised in $0.05 \mathrm{M}$ phosphatebuffered saline $(\mathrm{pH} 7.5,0.9$ p. $100 \mathrm{NaCl}$ and 0.1 p. 100 sodium azide in $0.05 \mathrm{M}$

\footnotetext{
* Present address : School of Biological Sciences, Universiti Sains Malaysia, Penang, Malaysia.
} 
phosphate buffer). Each homogenate was left at $4^{\circ} \mathrm{C}$ overnight and then centrifuged at $1000 \mathrm{~g}$ for $20 \mathrm{~min}$. at $4{ }^{\circ} \mathrm{C}$. Pituitary extracts, usually prepared at a concentration of 1 pituitary $/ \mathrm{ml}$, were stored at $-20^{\circ} \mathrm{C}$ and analysed within 10 days of being prepared. Plasma samples were stored at $-20^{\circ} \mathrm{C}$ prior to analysis.

c) RIA analysis. - A post-precipitation double antibody RIA technique was employed. Purified carp gonadotrophin, which was equipotent to $\mathrm{NIH}-\mathrm{LH}$ in the frog

\section{TABLE 1}

Comparison of parallelism of inhibition curves of plasma and pituitary extracts of various fish species with that of the standard hormone in both radioimmunoassays

\begin{tabular}{|c|c|c|c|c|}
\hline \multirow{2}{*}{ Species } & \multicolumn{2}{|c|}{ Homologous RIA } & \multicolumn{2}{|c|}{ Heferologous RIA } \\
\hline & Plasma & PE & Plasma & $\mathrm{PE}$ \\
\hline $\begin{array}{l}\text { Oncorhynchus spp. (3 species) } \ldots \ldots \ldots \ldots \ldots \\
\text { Solmo gairdneri }\end{array}$ & $\mathbf{P}$ & $\mathbf{P}$ & $\mathbf{P}$ & P \\
\hline $\begin{array}{l}\text { (a) wild } \ldots \ldots \ldots \ldots \ldots \ldots \ldots \ldots \ldots \ldots \ldots \\
\text { (b) hatchery reared } \ldots \ldots \ldots \ldots \ldots \ldots\end{array}$ & $\begin{array}{l}\mathrm{P} \\
\mathrm{np}\end{array}$ & $\stackrel{P}{\mathrm{np}}$ & & $\mathbf{P}$ \\
\hline $\begin{array}{l}\text { Salmo trufta } \ldots \ldots \ldots \ldots \ldots \ldots \ldots \ldots \ldots \ldots \ldots \ldots \ldots \ldots \ldots \ldots \ldots \ldots \ldots \\
\text { Salmo salar } \ldots \ldots \ldots \ldots \ldots \ldots\end{array}$ & $\mathbf{P}$ & p & $\mathbf{P}$ & $\mathbf{P}$ \\
\hline (a) parr $\ldots \ldots \ldots \ldots \ldots \ldots \ldots \ldots \ldots \ldots \ldots$ & $\mathbf{P}$ & P & & \\
\hline 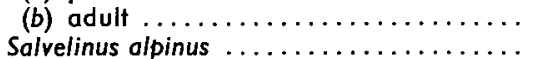 & p & & & $\begin{array}{l}\mathbf{P} \\
\mathbf{P}\end{array}$ \\
\hline $\begin{array}{l}\text { Coregonus lavarefus } \ldots \ldots \ldots \ldots \ldots \ldots \ldots \ldots \\
\text { Plecoglossus alfivelis } \ldots \ldots \ldots \ldots \ldots \ldots \ldots\end{array}$ & np & $\begin{array}{l}\mathrm{p}(\mathrm{np}) * \\
\mathrm{np}\end{array}$ & & $\begin{array}{l}p \\
\text { np }\end{array}$ \\
\hline $\begin{array}{l}\text { Esox lucius } \ldots \ldots \ldots \ldots \ldots \ldots \ldots \ldots \ldots \ldots \ldots \ldots \ldots \ldots \\
\text { Poecilia latipinna } \ldots \ldots \ldots \ldots \ldots \ldots \ldots\end{array}$ & -ve & np & & $\begin{array}{l}p \\
p\end{array}$ \\
\hline 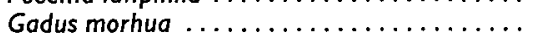 & -ve & np & & \\
\hline Pollachius pollachius $\ldots \ldots \ldots \ldots \ldots \ldots$ & & np & & p? \\
\hline Trisopterus luscus.... & & -ve & & $\mathrm{p}$ \\
\hline Anguilla anguilla $\ldots \ldots \ldots \ldots \ldots \ldots \ldots$ & & np & & np \\
\hline Protopterus sp. $\ldots \ldots \ldots \ldots \ldots \ldots \ldots \ldots \ldots$ & & np & & $\mathrm{P}$ \\
\hline Pterophyllum scalare ... & & np & & p \\
\hline Pleuronectes platessa $\ldots \ldots \ldots \ldots \ldots \ldots \ldots$ & & np & & np \\
\hline Dicentrarchus labrax $\ldots \ldots \ldots \ldots \ldots \ldots$ & -ve & $n p(-v e) * *$ & & np \\
\hline Perca fluviatilis $\ldots \ldots \ldots \ldots \ldots \ldots \ldots$ & & & & - ve \\
\hline $\begin{array}{l}\text { Morone saxatilis } \ldots \ldots \ldots \ldots \ldots \ldots \ldots \\
\text { Ambloplites rupestris } \ldots \ldots \ldots \ldots \ldots\end{array}$ & & & & $\begin{array}{l}P \\
p ?\end{array}$ \\
\hline Mugil labrosus ..................... & & $-v e$ & & \\
\hline Ictolurus punctatus $\ldots \ldots \ldots \ldots \ldots \ldots$ & & np & & $\mathbf{P}$ \\
\hline Scomber scomber $\ldots \ldots \ldots \ldots \ldots \ldots \ldots \ldots$ & np & np & & np \\
\hline Cyprinus carpio ..... & np & np & & $\mathrm{P}$ \\
\hline Carassius auratus $\ldots \ldots \ldots \ldots \ldots \ldots \ldots$ & & np & $\mathbf{P}$ & $\mathrm{p}$ \\
\hline Carp-goldfish hybrid $\ldots \ldots \ldots \ldots \ldots \ldots$ & & $\mathrm{np}$ & P & p \\
\hline Puntius gonionofus $\ldots \ldots \ldots \ldots \ldots \ldots \ldots$ & & & & $\mathrm{p}$ \\
\hline Rutilus-rutilus $\ldots \ldots \ldots \ldots \ldots \ldots \ldots$ & & & & p \\
\hline Scardinius erythrophthalmus $\ldots \ldots \ldots \ldots$ & & & & np \\
\hline Catostomus commersoni $\ldots \ldots \ldots \ldots \ldots$ & & & & p \\
\hline Petromyzon marinus. . . . . . $\ldots \ldots \ldots \ldots$ & & np & & $\mathrm{p}$ \\
\hline Lampetra fluviatilis. . . . . . . . . . . . . . & & & & $\mathrm{p}$ \\
\hline Scyliorhinus canicula $\ldots \ldots \ldots \ldots \ldots \ldots \ldots$ & & $-v e$ & & -ve \\
\hline
\end{tabular}

Abbreviations : PE pituitary extract ; RIA radioimmunoassay ; $p$, inhibition curve of sample being parallel to that of the standard ; np, inhibition curve not parallel to standard curve ; -ve, no cross reaction ; $p$ ? parallelism questionable due to incomplete inhibition curve.

* Infrequent parallelism between standard and sample observed.

** Infrequent cross reaction observed. 
spermiation bioassay (Fontaine, personnal communication), and salmon gonadotrophin, SG-DEAE-3 which elicited an almost 100 p. 100 response in the goldfish spermiation bioassay at a dose of $0.3 \mu \mathrm{g} / 10 \mathrm{mg}$ body weight (Donaldson et al., 1972) were used for radioiodination and as standards.

Ten-20 serial dilutions of a known quantity of pituitary extract were analysed in duplicate so as to obtain inhibition of binding of the label to the antibody over a range of 10-90 p. 100. Plasma samples were assayed at more than 3 serial dilutions.

\section{Results.}

A comparison of parallelism of inhibition curves of plasma and pituitary extracts of various fish species with those of the standard hormone in both RIAs are shown in table 1.

In the homologous RIA, the inhibition curves of both pituitary extracts and plasma of all Oncorhynchus spp., adults and precocious male parr of the Atlantic salmon, Salmo salar, adults of Salmo trutta, Salvelinus alpinus and wild Salmo gairdneri were parallel with that of the standard, SG-DEAE-3. However, samples from hatchery-reared Salmo gairdneri gave non-parallel inhibition curves; similarly non-parallelism of inhibition curves were found with pituitary extracts of the powan, Coregonus lavaretus, and the ayu, Plecoglossus altivelis, as well as 13 other non-salmonid species, while 3 species showed no cross-reaction. Thus samples of only some salmonids appear to crossreact in a manner identical to that of the standard in the homologous RIA.

In the heterologous RIA, pituitary extracts of all cyprinids and salmonids tested gave inhibition curves that were parallel to that of the standard, a purified carp gonadotrophin (BG2-116 or BG4-240), except for those of Plecoglossus altivelis and Scardinius erythrophthalmus. Nine other species, including 2 species of cyclostomes, Petromyzon marinus and Lampetra fluviatilis showed parallel inhibition curves while 4 others showed non-parallel inhibition curves. No cross-reaction was observed with the pituitary extracts of Perca fluviatilis and Scyliorhinus canicula at the dosage tested. The heterologous RIA therefore appears to be less species-specific than the homologous RIA.

\section{Discussion.}

The data indicate that even with the use of two RIA systems employing the same antiserum, the degree of immunological cross-reactivity of samples from various species depends on the nature of the purified hormone used as the label and standard. It is important to realise that these immunological observations are based on the ability of the test samples and standard to inhibit the binding of the labelled hormone on the particular sites on the antibodies. Thus in general, though not without reservation, if identical antigenic determinants are present in both the unknown samples and the standard hormone, the various inhibition curves of test samples and the standard hormone should be parallel whereas if the inhibition curves of the test samples from a particular species are not parallel with that of the standard hormone, then identical antigenic determinants are absent.

In the homologous RIA, the majority of the salmonids tested showed inhibition curves which were parallel to that of the standard hormone. Similar findings have 
been reported by Crim ef al. (1975), who employed another salmonsalmon homologous RIA which was separately developed. Non-parallelism of inhibition curves was, however, not reported by these workers. The non-parallel inhibition curves obtained from pituitary extracts of the hatchery-reared fish though not from the wildcaught, Salmo gairdneri emphasizes the need for caution in evaluating the immunological reactivities of similar species derived from different sources. Similar non-parallelism observed in 13 other non-salmonid species further reflects the zoological specificity of this homologous RIA system. Similar observations have been reported by Breton ef al. (1973) using a carp-carp homologous RIA.

This is the first time that common antigenic determinants have been demonstrated between the pituitary extract of a cyclostome and the gonadotrophin of a teleost. This is particularly interesting since there is no evidence for the presence of thyroid stimulating hormone in the Agnatha (Sage, 1973), though a gonadotrophin has been shown to be present in the pituitary on the lamprey investigated in the present work (Dodd et al., 1960).

The above findings, though based on a limited number of species, do not appear to be consistent with known phylogenetic relationships (Greenwood ef al., 1966). It is, however, not surprising that within a group as diverse as the fishes, certain antigenic determinants in the gonadotrophin molecule are common to a number of species.

While parallelism between the inhibition curves of a pituitary extract and the standard hormone is a prerequisite for the estimation of potency by RIA, more rigorous validation procedures must be performed before the RIA is employed for a particular species, these should include an investigation of the possibility that non-gonadotrophic glycoproteins may interfere in the system. This is particularly essential in the heterologous RIA in view of the wide cross-reactivity observed with pituitary extracts of various species. Furthermore, in many of the species tested, there remains a need to determine whether the RIA values correspond to the biological activity of the samples.

Symposium sur la Reproduction des Poissons Paimpont, France, 19-21 septembre 1977.

Acknowledgements. - We are indebted to Drs. J. F. Leatherland, J. N. Ball, H. Kobayashi and others for sending us some pituitary and plasma samples, to Dr. E. $M$. Donaldson and Dr. E. Burzawa-Gérard for the various purified gonadotrophin fractions, and to the Universiti Sains Malaysia for an Academic Staff Training Fellowship to the senior author.

Résumé. Les extraits hypophysaires et les plasmas de 35 espèces de poissons sont testés dans deux systèmes de dosage radioimmunologique (RIA), un système homologue saumonsaumon et un système hétérologue saumon-carpe, dans lequel le même antisérum, contre la gonadotropine de saumon SG-G100, est employé. Dans le RIA homologue, pour la plupart des espèces de salmonidés testées, excepté le Lavaret et le Plecoglossus, la réaction croisée est identique à celle obtenue avec le standard SG-DEA-3. Un non-parallélisme des courbes d'inhibition est observé pour 13 espèces non salmonidés, tandis que 3 autres ne montrent pas de réaction croisée. Dans le RIA hétérologue, tous les cyprinidés excepté le Rotengle et tous les salmonidés, excepté le Plecoglossus, de même que 9 autres espèces, donnent des courbes d'inhibition parallèles à celles du standard, la gonadotropine de carpe purifiée. Ces résultats montrent que les propriétés immunologiques des gonadotropines de poisson sont sans relation avec ce qui l'on sait de leurs relations phylogénétiques. 


\section{References}

BRETON B., BILLARD R., JALABERT B., 1973. Spécificité d'action et relations immunologiques des hormones gonadotropes de quelques téléostéens. Ann. Biol. anim. Bioch. Biophys., 13, 347-362.

CRIM L. A., WATTS E. G., EVANS D. M., 1975. The plasma gonadotrophin profile during sexual maturation in a variety of salmonid fishes. Gen. comp. Endocrinol., 27, 62-70.

DODD J. M., EVENNETT P. J., GODDARD C. K., 1960. Reproductive endocrinology in cyclostomes and elasmobranchs. Symp. zool. Soc. London, 1, 77-103.

DONALDSON E. M., YAMAZAKI F., DYE H. M., PHILLEO W. W., 1972. Preparation of gonadotrophin from salmon (Oncorhynchus tshawytscha) pituitary glands. Gen. comp. Endocrinol., 18, 469-481.

GREENWOOD P. H., ROSEN D. E., WEITZMAN S. H., MYERS G. S., 1966. Phyletic studies on teleostean fishes, with a provisional classification of living forms. Amer. Mus. nat. Hist. Bull., $131,341-455$.

SAGE M., 1973. The evolution of thyroidal function in fishes. Am. Zool., 13, 899-905.

TAN E. S. P., 1976a. Radioimmunoassays for fish gonadotrophin. Gen. comp. Endocrinol., 29, 252 (Abstr.), 8th Conf. europ. comp. Endocrinol.

TAN E. S. P., 1976b. Some aspects of the reproductive physiology of teleosts, with special reference of the seabass Dicentrarchus labrax. Ph. D. Thesis Univ. Wales, 280 p. 